\title{
Polysemic, Polyvalent and Phatic: A Rough Evolution of Community With Reference to Low Carbon Transitions
}

\author{
Gerald Taylor Aiken* \\ Department of Geography and Spatial Planning, Identités, Politiques, Sociétés, \\ Espaces; Université du Luxembourg
}

\begin{abstract}
This article addresses the varying interpretations, idealising and use of community, with specific reference to the way community is mobilised, deployed and put to work within the transition to low carbon futures. It surveys the broad heritage of community from nineteenth century sociology to more recent post-structural interpretations, including community as a governmental technique. This backdrop of wider understandings of community is now reflected in the emerging field of community low carbon transitions. The paper looks to the multiple, overlapping yet categorically different communities implied in this theoretically and empirically burgeoning field.

First, and in common with community's social science heritage, this article argues that community is polysemic. That is, it carries within it wide and varied semantic associations; importantly - amongst small-scale, place or rurality - requiring commonality and a border. Digging deeper, community also has a concurrent social theory legacy beyond referred semantic association. Here community is polyvalent, capaciously involving many different and overlapping values: from exclusive belonging, exclusion of others and difference, a more governmental fostering of correct conduct and good behaviour, to a feeling of belonging or acceptance that goes beyond semantics. Lastly, and innovatively for this area of study, the paper addresses community as phatic communication. Here, community has no meaning, nor does it imply shared or encouraged values. Rather community is reduced to gesture, which transforms understanding the way community is used in meeting low carbon challenges.
\end{abstract}

Keywords: Low Carbon Transitions, Community, Environment, Polysemic, Polyvalent, Phatic. 
p. 127. Polysemic, Polyvalent and Phatic: A Rough Evolution of Community With Reference to Low Carbon Transitions

\section{Introduction}

Regularly community is seen as aiding and abetting attempts to mitigate climate change, from possibilities to further renewable energy projects (Catney et al., 2014; Eadson and Foden, 2014; van Veelen and Haggett, 2016), to community's perceived ability to engender low carbon living to those within its bounds (Middlemiss, 2011a, 2011b). Movements such as Carbon Rationing Action Groups (CRAGs), EcoTeams, Carbon Conversations, and many more, all claim community as a particularly effective social arrangement in reorientating people towards more ecologically aligned lifestyles (Büchs, 2014; Taylor Aiken, 2015). Given all this, it is not surprising that community abounds as what Eadson calls a 'policy object': the mechanisms used by states to 'enrol people and places in energy-carbon action' (2016: 4). Less often acknowledged though, is community's role in adapting to environmental challenges. Alternative ecovillages have regularly assumed that they will be better places to ride out whatever shocks may befall mainstream wider society. Dark Mountain, an artistic collective that bleakly and firmly denies the possibility of ever mitigating the worst effects of climate change, still holds out hope that some form of community will allow human survival. The Transition Network (transitionnetwork.org) also envisions a future where places are less reliant on precarious supply chains of economic flows: when these alter drastically, Transition's 'resilient relocalised community' will not only remain secure, but also be a model for others to follow (Aiken, 2012).

Community, as both an adaptive and mitigatory response to environmental challenges, including climate change, needs to be taken to task. When one word, concept or idea can cover so much ground, researchers need to be fully alert in our critical capabilities. This means not only being alive to what community might mean in any given situation, but also what effects community can (or is assumed to) produce. The point here is that being alive to these questions could raise other difficult and hidden possibilities: perhaps community means nothing whatsoever? Perhaps community is merely a gesture, functioning like a wave to acknowledge another's presence, or as a dismissive shooing away.

While community empirically proliferates as a grassroots response to global environmental challenges, governments are increasingly interested in using community to meet their legal, logistical and even moral low carbon commitments. However, the community implied is not consistent. This article weaves community's intellectual heritage with current low carbon use. In charting community's longue durée, the article first reemphasises a fundamental sociological point, that community can mean different things to different people: across time and space community is polysemic. Within the policies and projects using community as a tool, community is commonly understood to refer to place, but also interest or communion. However, each of these community policies often reproduces an essentialist reading of community, firmly wedded to community as a border containing commonality, based in some way on the work of Tönnies (1887). The first section (Polysemic Community I) makes this point, before going on to look to anti-essentialist readings of community (Polysemic Community II). However, rather than halting the critique there, the argument is that both essentialist and anti-essentialist, 'traditional' and deconstructed community, attempt to link community to a signifier (however loosely). The bounds of community are pushed beyond borders and homogeneity towards difference, antagonism, a porous border not a carapace; yet this article argues that attempting to fully appreciate what community is, does and could be, needs to move beyond semantics.

To this end, the article moves on to utilise communitarian and governmental understandings of community in order to understand the implied values and morals community is believed to engender. Here, community is polyvalent (Section 3: 
p. 128. Polysemic, Polyvalent and Phatic: A Rough Evolution of Community With Reference to Low Carbon Transitions

Polyvalent Community). The argument then builds to offer an original and useful way to grasp a theoretically neglected use of community in low carbon transitions. Identifying community when used without semantic meaning, a desire to to promote "community values' or even to corral deviant tendencies can be described as phatic community. Community as phatic captures the way in which the overuse and overburdening of the term community renders it meaningless aside from its role as gesturing toward an assumed shared intuitive understanding. In this way, the article offers an exploration of how community can come to say more about contact than content.

\section{Polysemic Community (I) - borders and homogeneity}

Identifying community as polysemic implies that community can be used as a multiple signifier, used to different ends by different actors at different times. This article first argues that community is an open rather than an empty signifier, semantically linked to a plurality of meanings, some more sedimented than others. Consistent in its inconsistency, community has historically lent itself towards particular different interpretations and understandings. For instance, regular elisions of community with small-scale, local and neighbourhood level associations have been particularly evident. For those involved within any given community a different set of more affective, phenomenological overtones have been understood: warm, close, friendly, belonging, or more negatively, closed, constraining, socially stifling. Community can also imply action, activity, and getting things done. Community, of interest or of place, was, and is, used in different ways, at different times, by different actors. In short, community is internally multiple, diverse and polysemic.

Social Science writings on community typically begin with Ferdinand Tönnies (Bell and Newby, 1971). Writing in the nineteenth century, Tönnies became concerned with what he saw as rapidly disappearing community (1955 [1887]). He identified this as an effect of what he characterised as two strong social forces ushering in 'modern society': the industrial revolution and increasing urbanisation. Far from being indifferent to these processes, Tönnies had no doubt that this loss of community was a bad thing. His anti-urban and anti-modern stance regarded 'modern society' lacking morality. Characterising this transforming social fabric he made a distinction between Gesellschaft and Gemeinschaft. By Gesellschaft Tönnies indicated 'society' or 'association': a form of togetherness he diagnosed as fast replacing Gemeinschaft: regularly translated into English as 'community'. For Tönnies Gemeinshaft brought associations of traditional, rural, village and morally based social order that connoted the familial, intimate, and personal. Tönnies' conception of Gemeinschaft was positive and embodied a yearning for this disappearing form of being with others (Lee and Newby, 1983: Ch.3).

Despite many key nineteenth century sociologists discussing community - inter alia, Durkheim, Weber and Simmel - Tönnies is referred back to most often from this period. Cohen, for instance, points out that writing on community has often been based on 'a highly selective reading of Tönnies' (1985: 11). Two of the most comprehensive recent historical surveys of writing on community both trace the concept back to Tönnies. Delanty (2010: 21-23) describes Tönnies's community as a core 'myth of modernity', redolent of tradition, rurality, locality, friendliness and positivity. Delanty returns to the late nineteenth century writings, counterpoising Tönnies with Durkheim, Weber and Simmel. Reaffirming this period as the age of the 'birth of community', Delanty is concerned with showing how community has wrongly been interpreted in opposition to society. Yet community was, and continues to be, framed predominantly through Tönnies' Gemeinschaft/Gesellschaft distinction and departure point. 
p. 129. Polysemic, Polyvalent and Phatic: A Rough Evolution of Community With Reference to Low Carbon Transitions

Bauman (2001) on the other hand, is less concerned with charting the various interpretations of community than with community's persistent association with loss. Bauman (2001: 8) implies that longing for a past world is inherent to community, closely linking it to the myth of Tantalus. For environmentalists too this collective utopian togetherness is often tantalisingly close in futures as well as pasts. For instance, Dark Mountain conclude their Uncivilisation manifesto 'Together, we will find hope beyond hope' (Dark Mountain, 2009). Bauman's community ennui is a temporally out of reach 'understanding shared by all its members' (2001: 9). Bauman's approach to community allows and leads toward an analysis of the internal components of community, such as belonging, rather than an exclusive focus on external definers: territory, place or rurality. Yet both Delanty and Bauman inherit the tradition of writing on community, paying respect and deference to the nineteenth century sociological fathers, particularly Tönnies.

From this beginning three (not necessarily exclusive) separate strands in which 'community' has been understood semantically can be identified:

(1) Community of place. Here community emerges from lived experience, within a shared location, be it a small village, neighbourhood, street or other such shared proximate relationship. Community of place, location-bound, can be seen as the 'Straw Man' or 'Aunt Sally' of much of Community Studies. Yet the belief that community is naturally, or commonly, based in a particular location, area, or territory, is still used and useful. Markantoni and Woolvin (2015) highlight the rural communities of place found in various Scottish low carbon initiatives: Community And Renewable Energy Scheme, Climate Challenge Fund, Community Powerdown, Scottish Sustainable Communities Initiative, Transition Support Scotland and many more. Jackson's writings indicate how this community of place is understood to be the natural and effective vehicle for low carbon living. Jackson claims that 'individual efforts to live more simply are more likely to succeed in a supportive community' (2009: 150), providing examples such as the Findhorn Foundation, an intentional community of place with a self-declared aim of 'living simpler, more sustainable lives' (loc. cit.). In literature on grassroots social innovations within socio-technical transition theory, community is commonly linked to or emerges from particular places and local contexts (Seyfang and Smith, 2007; Seyfang and Longhurst, 2013; Heiskanen et al., 2015). Closely linked, and commonly within geography, community responses to environmental challenges are semantically fused and elided with small-scale (Bulkeley and Newell, 2010: 70-86), taking one level in a multiscalar approach (Bulkeley, 2005). The empirical example par excellence here is Transition Towns. Constructing this kind of community relies on normative locationbound assumptions and the homogenous nature of shared goals.

(2) Community through interest. Here community is again formed through something shared, be it belief, occupation or pastimes. Thus we can talk of the 'environmentalist community', or a community of those who build low impact housing (Pickerill, 2011). These communities can be intentional (i.e. deliberately opted-into), or unintentional, given through descent ('the Jewish community' in those branches where membership is deemed to come from the mother), or identity based ('the scientific community'). Epistemic communities are one way to avoid assuming community as inherently place-based and local (Lovell, 2014). Bulkeley and Newell (2010: 8) describe the Intergovernmental Panel on Climate Change (IPCC) as an epistemic community united by shared understandings and normative beliefs around climate change. Büchs's (2014) review of community-scale environmentalism includes CRAGs or Ecoteams where like-minds help 'reinforce' participant's low carbon living. Despite their place-bound moniker, Transition Town initiatives are often comprised of likeminds, albeit targeting a particular place, hence the name. Cochrane (2007: 48) claims community in UK policy ultimately means only one of two things: a territorially 
p. 130. Polysemic, Polyvalent and Phatic: A Rough Evolution of Community With Reference to Low Carbon Transitions

delimitated neighbourhood, or identifiable ethnic group. These could broadly map onto these two categories, but there is a third aspect of community to consider.

(3) Community in communion. This is the 'spirit of community', or feeling of belonging, which can exist without the first two factors. Groups who have been though a shared experience - from groups of refugees, to university graduating classes - can recognise a community spirit not based on place or specific interests. Community may be forged through shared experience, practice or identity, but is sustained across interest or place. The Muslim Ummah, or the Christian Communion of Saints, assumes a collective belonging beyond place or interest. Belonging to these communities is defined in some way by commonality, a shared feeling, experience or condition.

Within these three varieties of community two factors remain crucial in this 'traditional' understanding of community. These are the need for community to have an in/out definer: however (in)visible, each community has a border. Second, those inside the community border have something in common to define their belonging. Whether location of residence, area of interest, ethnicity, religion, or even shared experience there exists homogeneity.

Early writers on community, such as Redfield (1955) and Tönnies (1955 [1887]), identify internal homogeneity and existence of a border as a precondition for the possibility of community (Bauman, 2001: 13). The community border could be a line on the map, or physical boundaries such as rivers, mountains, or valleys. Additionally there are social borders and barriers that structure separations. Communities displaying a high degree of homogeneity can be found in examples such as the Amish, or more obvious borders to gated communities. That borders and homogeneity are essential for the possibility of community is emphasised when these factors are lesser: the community bounds are seen as somehow fostering weaker affiliations. For example, a community of stamp collectors is assumed to have a lower degree of community than the Amish.

Of course borders and homogeneity are related and often come in pairs. Hillary relates community to prison, "being a social system that not only tended to regulate the total lives of inmates but which also set barriers to the social interaction with the outside' (Hillary, in Bell and Newby, 1971: 36). Staeheli (2008: 6) argues that even when community is inclusive, this is based on exclusion: a necessary border and internal homogeneity of some kind. Cohen's (1985) focus on community's symbolic function identified how cultural boundaries are created in order to help the community function. At a larger scale, Anderson (1991 [1983]) famously outlined the processes, such as print capitalism, that helped create the Imagined Communities of nationalism. Crow and Allen (1994) investigate the changing nature of community as an object of study, focusing in particular on the impact of post-WWII economic change and geographic mobility on community. Another longstanding assumption in both the US and UK is, despite different theories, community is still seen as 'man's [sic.] natural habitat' (Bell and Newby, 1971: 22). This highlights the persistent nature of community, and it has continuing importance to social theory and social scientists today (Claviez and Nancy, 2016; Esposito, 2010; Nancy, 2016; Wills, 2012).

There are other recurring connotations in community readings, such as the nearubiquitous positive use, or the reified 'ideal type' manner of seeing community. However both these conditions of possibility - homogeneity and border - are constant in descriptions of community prior to post-structuralism. One could imagine community as a bad thing, however unusual a position that might be; but without a border or internal sameness it would not be a community. For example Morton (2010: 208) claims community is inherently fascist, but does so precisely because of its need for a 
p. 131. Polysemic, Polyvalent and Phatic: A Rough Evolution of Community With Reference to Low Carbon Transitions

border and internal homogeneity. Community without these would not be community; immediately a question announces itself-a community of what exactly?

\section{Polysemic Community (II) In Extremis - deconstructing borders and homogeneity}

More recently community - ever subject to multiple interpretations - has even been questioned over these two near-universals: a border containing commonality. The alternative interpretations offered by a diverse body of broadly post-structuralist work makes key contributions. Community conceived of as inherently good, recently lost and to be recovered, still often lurks in the theoretical background. However, envisioning community as necessitating a border or as homogenous has been profoundly challenged.

For instance, Habermas $(1984,1987,1998)$ proposes a theory of Dialogical Community, through which he characterises community existing opposed to established organisations, undergirding social norms. Community here is not just a social arrangement or aggregation of individuals, but the fundamental basis for relatedness between people, before and beyond any organisation or movement (Elliott, 2009: 896). Under Habermas's analysis, community - rather than a social democratic welfare state, or laissez-faire capitalism - forms the basis for civil society, and ultimately for the state. Habermas's argument for this is that only in community do other people cease to become 'Other'. This community is a necessary extension of the self, opposed to prevailing market norms and also the basis for 'genuine' democracy.

Young (1990: 231) pushes Habermas's innovative contribution to understanding community further, combining it with Derrida's notion of the co-presence of subjects. She argues that if community is a primary mode of experiencing the world, and we are each different individuals, then far from commonality characterising community, we ought to think of community as inherently (and internally) diverse. Consequentially, the way we theorise, understand, and use community shifts. Once we recognise community's diversity, particularly our experience of it, attempts to homogenise community become not only counterproductive but also reactionary.

For Agamben (2003) and Nancy $(1991,2016)$ - both Derrideans like Young community is a key concern. Both take different starting points to Habermas's community, as a natural or essential extension of the self, and as foundational for organisations or the state. For this reason, they also reject Young's analysis of community that builds on Habermas' framework. Community for both Agamben and Nancy is singular, rather than dialogical (Elliott, 2010). Agamben's The Coming Community (2009), rejecting essentialism, stakes out his ground. Community cannot be based upon any commonality: 'there is no essence, no historical or spiritual vocation, no biological destiny that humans must enact or realize' (2009: 43). Community for Agamben emerges as any singularity demonstrating 'being-in-common'.

Agamben's conception of community is radically subversive. Against 'traditional' understandings of community - particularly the 'community of place' Straw Man Agamben argues that there is nothing inherent, given or natural about community. Community is emergent, not essential. Agamben is not the first to make this claim, but it marks a strong departure from previously accepted community semantics. Yet because it rejects divisions based on identity, politics, or more abstract bases, community under Agamben's interpretation emerges as profoundly affirming. It becomes a unifying condition of our being- and becoming-together with others, against any imposed community categorisation. Community becomes the principle enemy of the State. Wherever these singularities peacefully demonstrate their being in common there will be a Tiananmen' (2009: 87). 
p. 132. Polysemic, Polyvalent and Phatic: A Rough Evolution of Community With Reference to Low Carbon Transitions

For Nancy, community is experienced as loss: "the dissolution, the dislocation, or the conflagration of community ... [is] the gravest and most painful testimony of the modern world' (1991: 1). But this nostalgia for community is not what it used to be. Nancy's community is a 'myth', yet - like all myths - is no less powerful or evocative. Community cannot possibly be built or fought for, rather it just is. Community here is both primary, in that it is key to what it means to be human, while also being mythic in the way it is represented and thought of. 'One does not produce it [community], one experiences or one is constituted by it as the experience of finitude' (Nancy, 1991: 31).

We can identify the strong influence of Derrida on Young, Agamben and Nancy through the way they seek to challenge established boundaries, binaries, and assumptions. Particularly in Young, Derrida's influence aids a strong focus on the inherent diversity of community. Caputo's writing on community has the same tendencies and influences. Turning to analyse the etymology of community as Derrida plays with it, Caputo identifies the root words com munis, that is, a common defence (Caputo and Derrida, 1997: 107-108), to suggest that community means a violent exclusion of the Other. Because of this, Derrida (2000) wished to replace community with hospitality (hostilis polis), to give power to the stranger, or enemy. There are two problems with this interpretation and approach. First, however interesting or useful it may be, etymology is not proof. Second, on this particular point, in English at least, Derrida's claim seems far from uncontested. Community, as a word comes from the Anglo-Norman, middle-French communité, referring merely to joint ownership. The earliest use of community in English (from around 1400 onwards) seems to refer to little more than viewing people as a collective. The point is not to make linguistic argot here, rather to emphasise the lessons social theorists took from this view on community. Broadly post-structural, or culturally inflected understandings of community challenged what were reasonably settled divisions and boundaries. Crucially though, this challenging of community, even when radically re-evaluating the term, is done so within semantic parameters, community is claimed to mean or not mean certain things.

It is a fool's errand to be exhaustive when analysing terms like community. However, this array of divergent community theories and appropriations between oftenopposed understandings and receptions of community, are not as different as they appear. Demonstrating this consistent variety from nineteenth century sociology to more recent post-structural approaches, community is received in many and varied ways. What appeared to be common threads at one point - the need for a border or commonality - have been superseded. Yet, through each of these evolutions community means something. A semantic association has been drawn or referred to. Or, alternatively, reacted to and argued against.

The same is regularly found when community is brought to bear in environmental politics. This community has a semantic association drawn to it. Inter alia, community as: a context for individual behaviour change (Jackson, 2005, 2009; Moloney et al., 2010; Mulugetta et al., 2010); a site of eco-localisation (North, 2010) or ethical placemaking (Mason and Whitehead, 2012; Franklin and Marsden, 2015); a grassroots innovation readying itself for the mainstream (Seyfang and Smith, 2007; Middlemiss and Parrish, 2010; Seyfang and Haxeltine, 2012; amongst many others); or as an egocorrective, a locally rooted technology of governance (next section). Community can be a space outside prevailing norms, where alternatives can be practised or experimented with, as an alternative 'community economy' (Gibson-Graham, 2006; Gibson-Graham et al., 2013). Regularly, community is also associated with a more sustainable, just and enriched life (Agyeman, 2005; NEF, 2010; Bulkeley and Fuller, 2012). Low carbon communities are also linked to new or alternative collective living arrangements, such as co-housing (Chatterton, 2013, 2014) or eco-building (Seyfang, 2009; Moore and McKee, 2012; Pickerill, 2016). Usefully, Walker (2011) clusters the various 
p. 133. Polysemic, Polyvalent and Phatic: A Rough Evolution of Community With Reference to Low Carbon Transitions

communities invoked in carbon governance as synonymous to: place, network, process, identity, actor or scale.

It may seem banal and straightforward to state that where community is used it means something; it has a variety of semantic associations. Yet, as we shall see, this semantic link and the possibility of community without any semantic meaning have important consequences for understanding community low carbon transitions. Community is also prevalent not only for what it does or could mean, but for its additional potential to resubjectify selves. The article next turns to the morality or values tied up with community - present from community's 'beginning' with Tönnies as understood by academics, practitioners and policy-makers. This polyvalent community is also linked to literature on governmentality, a moralising community used to get people to behave; community for correct conduct.

\section{Polyvalent community}

Nikolas Rose outlines community's history as an object of study or descriptive analysis, as the first two sections here have done. In each period 'community' was polysemic: from being counterpoised to society, emerging from the industrial revolution, the loss of tradition and rise of individualism, next to the 'damaging effects of metropolitan life in the 1920s and 1930s' (1999: 172) through Community Studies analysis after WWII, concerned with the 'apparent anomie created by the disturbance of 'settled' working class urban communities' (1999: 172), and the professional services of the 1960's and 1970's community workers. The community Rose discusses follows these, and is different: 'any similarity is a little misleading. The community appealed to is different in different cases: differently spatialized and differently temporized' (1999: 172). Again, community is similar in the dissimilar ways it means something. We can - following Rose - describe community up to the Third Way as the era of community as primarily polysemic. After this, the question of what - if anything - community means begins to fade, though not entirely. The more interesting, instructive question becomes the values, ethics and morals inherent within the form of togetherness known as community.

Investigating community then is perhaps best not done directly, through an attempt to clearly see what it means. Rather, the less direct route might be to approach community from the side: what does community feel like? What changes to behaviours, practices and beliefs does it encourage? What does community affect? What affects are present within community? And why does community feel affirming and cosy, or stifling and suffocating? Frazer (1999: 76) suggests this approach to community is by seeing it as a value. However, as with the semantic approach above, these values are many and varied, hence outlining community as not only polysemic, but also polyvalent.

Community as a value has often been a mobilising concept for those on the political Left, akin to the French Revolution's fraternity, or as Featherstone has shown for Solidarity (2012). This goes alongside Douglas's (1966) view that community symbolised an attitude as much as a description. For environmentalists this has also been the case. For grassroots activists, community is often the approach that will 'solve' climate change. The popular Transition Town movement outlines this as clearly as any other: 'If we wait for individuals it will be too little, if we wait for governments it will be too late, but if we act as a community, it'll be just enough, just in time.'1

Many other grassroots environmental movements use community as a way to encourage each other and keep on track. Research claims community has particular potential to reorientate or correct environmental behaviours (Heiskanen et al., 2010; Middlemiss and Parrish, 2010; Middlemiss, 2011a, 2011b; Bradbury and Middlemiss, 
2014). Shirani et al (2014) gave various examples of how 'alternative communities' can foster and encourage members to lead low carbon lifestyles and hold these values. Howell (2013) links involvement in collective low carbon living to those holding 'biospheric values' though makes no causal claim about this congruence. For Jackson (2009) community is the required solution for environmental challenges, and belonging to community correlates with 'green living' or 'acting ethically'. The common assumption here is that belonging to particular forms of togetherness going under the name community acts as a sort of ego-corrective, taming individualistic or selfish desires. People are better citizens when in community.

Here, community is a technology of governance. A way of grasping and conceiving the world in which belonging to a community guarantees ideal social behaviour, in this case targeting carbon deviance. Various state schemes put community to work here; within the UK alone there is England and Wales's Low Carbon Community Challenge (DECC, 2012; Hauxwell-Baldwin, 2013) and Scotland's Climate Challenge Fund (Creamer, 2015a, 2015b; Taylor Aiken, 2014). In England local authorities are now statutorily obligated to produce a Sustainable Community Strategy, and there exists a Community Energy Strategy (DECC, 2014), alongside the wider application of community in schemes like Scotland's Community Empowerment Act.

From grassroots activists, in government policy and to some academics, community is an ideal response to environmental crisis. Each of these assume something about community which is not a semantic association per se, but rather a manner of behaving and belonging; Frazer's 'value' or Douglas's 'attitude'. Describing community Bauman stated: 'words have meanings, some words also have a feel' (2001: 1). The values, valences, and accompanying moral notions are tied up with community's functional shift from semantic understandings: from polysemy to polyvalence.

Much of this theoretically stems from Foucault and Foucaldians. Building on Foucault and appreciating community as a governmental strategy, Rose (1999: 167196) outlines how 'government through community' is both moralising discourse and governing technique. Rose charts community from polysemic understanding through to a category different community, capaciously encompassing different value systems; community as polyvalent. Rose states 'while the term 'community' has long been salient in political thought, it becomes governmental when it is made technical' (1999: 175).

Superseding power or control from only a central locus, Foucault outlined a dispersed capillary power. He used Bentham's ubiquitous panopticon to explain 'internal policeman' self-regulation invoked by states, by use of 'pastoral power', a notion Foucault takes specifically from Christianity (Foucault, 2009: 147). Pastoral power is distinct from political power. Pastoral power concerns the conduct of souls, and a "permanent intervention in everyday conduct, in the management of lives, as well as in goods, wealth, and things... It concerns not only the individual, but [also] the community' (Foucault, 2009: 154). Pastoral power is where moral community enters. It enters first as a separate space, free(er) from coercive state influence. Later as states begin to utilise such notions and techniques, this amounts to government by community. Foucault used the analogy of the pomegranate to outline how individuals within community, communities, and communities of communities are subject to this. 'The unity of the pomegranate, under its solid envelope, does not exclude the singularity of the seeds, but rather is made up from them, and each seed is as important as the pomegranate' (Foucault, 2009: 174). Thus community unites both individual and collective focus of pastorate power for Foucault.

This community first emerges as an alternative space to prevailing societal norms and pastoral power. The argument following Rose, below, is that it then becomes a 
space of enacting and sustaining such norms. Community shifts from being a site of counter-conduct, to enacting and sustaining state power (Taylor Aiken, 2016). The assumption throughout is that community is somehow particularly strong at enacting or engendering moral codes, but what that moral or value (valence) is varies.

The assumed values of community are not only found in Foucalidian critiques of community, but also in communitarian praising of community. Etzioni $(1995 ; 1997)$ ushered in the communitarian agenda - where morality, social order and social responsibility (his vision of community) were the tonic for (over) individualism. Etzioni, again, identifies community to be in decline. Community has been the subject of countless obituaries, and for communitarians this is bemoaned. Putnam (2000) famously analysed the decline and fall of the US civic realm, before setting out parameters for its possible return. The subtitle says it all Bowling Alone: The collapse and revival of American community. 'What good does community do us?' is asked of polyvalent community. 'Communitarianism draws its power from its ways of answering this question: its promise of a new moral contract, a new partnership between an enabling state and responsible citizens, based upon the strengthening of the natural bonds of community.' (Rose, 1999: 186). These moral values are in community at large, not only communitarianism. This is still relevant today and helps explain Big Society narratives as a rebranded form of communitarianism, or environmental governance assumptions linking community as a correlate of green living.

'In this way, bonds between individuals are rendered visible in a moral form, and made governable in ways compatible with the autonomy of the individual and the reproduction of the collective: the self must govern itself communally in the service of its own liberty, autonomy and responsibility.' (Rose, 1999: 186). Environmentalism has taken up this baton. Community is remarkably malleable in its interpretations, but also in the moral values infused within it. Yet this community morality can also collapse back to the polysemy it emerges from, particularly its two persistent conditions: a border and sameness. Witness Maclntyre: 'What matters at this stage is the construction of local forms of community within which civility and the intellectual and moral life can be sustained through the new dark ages which are already upon us' (1981: 145). But, for Rose, this relies on common and agreed cultural and political virtues for all citizens, problematic in a multicultural and pluralistic age.

This is relevant for a number of reasons. Community implying shared value systems as a 'natural state of being', or 'part of what it means to be human' is echoed in current environment movements and policy. 'This 'natural-ness' [of community] is not merely an ontological claim but implies affirmation, a positive evaluation.' (Rose, 1999: 168). North (2015: 14), following Gibson-Graham's work on community economies, recently called for 'culturally informed' geographers to be alive to 'other value systems', beyond the superficially visible, specifically highlighting sustainability and community. This is an appreciation that sustainability and community may well have meanings, but of at least equal importance are the values they are assumed to carry and perform. In environmental policy, it is not only the presumed elision between community's semantic meanings - for example with local - that is problematic, never mind inaccurately reflecting empirical evidence. It is also the assumed values or morality inherent within the form of togetherness that goes by the name community. In meeting environmental challenges, it is the corralling of citizens' moral behaviours that is of most use. Policy reports typically conclude 'community-led engagement is particularly effective' (IPPR, 2011: 42). When government schemes adopt community for targeting carbon deviance amongst populations it is not the specific meaning or semantics of community that are doing the work, it is the presumed values and morals of community. 
The shift from polysemic community to polyvalent is not epochal. Rather it is a new phase in which community can be thought of, rather than a definite line separating two eras. Community still functions as polysemic and polyvalent today. Community as "the third sector, the third space, the third way of governing, is not primarily a geographical space, a social space, a sociological space, or a space of services, although it may attach itself to any and all such spatializations. It is a moral field, binding people into durable relations' (Rose, 1999: 172). This is where Rose is relevant in excavating community's intellectual heritage, the way in which community pertains to a moralising discourse. Polyvalent 'community' comprises:

'a moral individual with bonds of obligation and responsibilities for conduct that are assembled in a new way-the individual in his or her community is both selfresponsible and subject to certain emotional bonds of affinity to a circumscribed 'network' of other individuals-united by family ties, by locality, moral commitment to environmental protection or animal welfare.' (Rose, 1999: 176)

Community became the answer, and the question is as much the moral degradation or deviancy of society, as it is about individuation, free market or overly centralised state power. Environmentally, community's perceived inherent values answer overconsumption, a lack of connection to or empathy for (environmental) others, or a more general carbon deviance.

\section{Phatic community}

Community carries a capacious array of different meanings and associations, values and ethical assumptions. Within environmental governance, community's polysemic and polyvalent function is also reflected. More recently, as community has proliferated as a response to low carbon challenges, it has come to not mean anything, nor refer to any implied shared sense of values. This article now suggests that community plays an important, though neglected, role as phatic communication. That is, that community when used to meet environmental challenges is often more about contact than content. Community serves a social function, opposed to conveying information per se. Community instead appears as - literally and semantically - meaningless and used only as gesture. Gestures can convey, clarify and intensify linguistic expressions, but the phatic language-as-gesture is itself devoid of such meaning. This is what is meant by the phatic use of community. Phatic communication here refers to the way governments and businesses feel socially compelled to adopt the term, or how grassroots, third sector organisations use community as an instrumental gesture, for instance to help secure funding. Here community is adopted or invoked without resting on any semantic understanding of what 'community' may mean, still less the ethical and moral implications within community's polyvalence. Phatic community's emergence moves beyond polysemic and polyvalent understandings.

In an article published in 1923 Malinowski introduced 'phatic communion' as language that does not 'primarily convey meaning', but rather 'fulfil[s] a social function' (Malinowski, in Jakobson, 1960: 315). Malinowski here is referring to his work with 'native peoples' but takes care to point out how phatic communion is also found in Western societies. He provides examples that still resonate. Imagine, for instance, two people passing each other, out walking one morning. As they approach, one remarks 'How are you?' and the other responds 'Hello, nice day'. There is nothing remarkable about this exchange, but the words themselves are precisely meaning-less. They indicate an acknowledgement of the other's presence, but the words communicated 
p. 137. Polysemic, Polyvalent and Phatic: A Rough Evolution of Community With Reference to Low Carbon Transitions

here function on the level of gesture. They may both have waved at each other and communicated as much.

Malinowski interprets this mode of communication as saying something deep about human nature. Phatic communion 'serves to establish bonds of personal union between people brought about by the mere need for companionship and does not serve any purpose of communicating ideas' (Malinowski, in Jakobson, 1960: 316). There is a curious link between this and the use of community in environmental governance. The word community pertains to affectations of a collective. A deep irony in the phatic function of community would be not that the word itself is devoid of meaning, but the wresting of meaning from community might be the reason for its wide appeal and ubiquity, none more so than in low carbon transitions.

Community has positive affectations, but these are gestured towards, rather than semantically meant. One reason this is accepted and so pervasive is perhaps due to the double-bind of phatic language. That is the way 'community' is used to serve a social need; for example establishing social bonds without tying those bonds directly to any reflected, derivative thought. The lack of a signification from the word or term community to semantic meaning is not necessarily because community somehow undergirds social reality. Community may well form a pre-reflective, pre-rational, prelinguistic extension of the self towards others, prior to and before any semantic reflection is possible, but phatic community takes a different argumentative approach. Here community is used trivially, flippantly, without import. And yet, community here is all the more important to study and investigate due to the effects this phatic deployment has.

Walker and Devine-Wright (2008) indicate a phatic use of community in relation to low carbon transitions, characterising the use of community in renewable energy projects as having wide and diverse meaning and application above all else. More particularly Warren and McFadyen (2010) suggest that merely using the word community can help to assuage objections to potential renewable energy initiatives like a wind farm. Phatic use of community is not only top-down though. Relatively large government funding schemes provide a carrot for volunteers and grassroots actors to adopt community language and rhetoric. 'Community', 'community action' and 'community-led' proliferates in grassroots responses to environmental challenges. Yet this may indicate no more than a group's understanding of how to use the language of funding schemes and demonstrate a capacity to adopt this in order to secure funds. In a previous study this was described as the word community serving to 'temper' more antagonistic, transformative language (Taylor Aiken, 2014: 214). DeFilippis et al (2006, 2010) point out how the overloading onto community of invested meanings, hopes and expectations, by a seemingly inexhaustible rage of actors, can leave the feeling that community is adopted as little more than a post hoc addition to whatever would have happened anyway: be it a neighbourhood plan, renewable energy infrastructure, grassroots activism. Walker et al. outlines community's 'functional malleability' (2007: 64). Here community can function not only as language with semantic meaning, but also as a gesture.

Phatic communication is 'a type of speech where ties of union are created by mere exchange of words' (Malinowski, in Jakobson, 1960: 315), essential in forming social ties. Wootton's research reveals the importance of phatic forms of communication in maintaining salient ties within Cairo. His analysis of social media networks that were sustained and sutured though apparently pointless communication recognises phatic communion being an enabling condition, for both group formation and even political action. Phatic communication, he claims, while being devoid of semantic meaning, delivers the underlying message 'you are worth communicating with, even if I have nothing to say' (2016: 48). The same underlying message can be seen to be delivered 
p. 138. Polysemic, Polyvalent and Phatic: A Rough Evolution of Community With Reference to Low Carbon Transitions

by energy companies adopting community labelling in order to assuage opposition, or as an 'effective strategic element in negotiations around planning consent' (Cass et al., 2010: 255). Such enterprises acknowledge you are worth acknowledging, even though they may not directly engage with you, or communicate anything in itself. Such an analysis also helps to understand why grassroots community groups can use the term community in an erratic, ubiquitous and cavalier manner. Or, at least it can appear like that to social researchers like myself whose ears are tuned to pick up any and all mentions of community. The term community is used not for any communication purpose other than to again confirm and reassure those in the group they are valued and worth time and energy.

Identifying community as a phatic term serves the following functions. Community is phatic when it creates or engenders social ties by its mere use, not what the word (possibly) refers to. Two, community is phatic when used as a gesture by energy companies or governments wishing for consent to their plans. That it may be required or encouraged by government policy may also lead to bottom-up actors doing the same. Each is socially and culturally compelled to adopt community, yet not mean anything by it. Three, as a word community has a capacious plurality of meaning. This does not require community to be necessarily meaning-less, just that it can mean vastly different things. This diversity of meaning can result in the term becoming so diluted that to find any meaning contained within the gesture is difficult. Four, the communication signifies something different to an inherent message contained within the word or series of words. It is communication without content. Therefore potential initiatives can give affectations of being for the good of 'local residents' when in actual fact they do no such thing; sometimes the opposite is a more accurate 'meaning'. In examples where community can be seen to have directly opposing effects to what a common sense or folk assumption of what community might refer to, Middlemiss (2014: 937) and Hauxwell-Baldwin (2013) have argued that UK government community energy policy entrenches individualisation of those funded. Eadson (2016) names these policy effects 'atomisation'.

An interest in phatic communion has enjoyed something of a renaissance recently. For Morton, 'phatic statements make us aware of the actual air between us' (2007: $37)$. In this sense phatic statements more about contact, and are self-referential in the sense that the contact is primarily about the contact. Rather than being designed to serve some means or other, such as a contact designed to communicate a message, here there is no message as such. Phatic statements are contact without containing content.

Žižek (2008: 67) has a slightly different understanding of phatic communion. He broadens the application of the term to include events, bringing the notion to bear on violence in Western society. For Žižek, violence, such as the French suburban riots of 2005, far from being explicable, or even understandable, is precisely meaning-less. Though it is not the lack of meaning that gives this act of violence (Žižek would say 'event') its phatic nature. Rather, violence, as an expression of impotence is not there to communicate any demands, but is itself the message to be delivered. It communicates that the protesters exist and functions as a way of checking that the channel of communication is open, like the start of a Skype call, repeatedly saying 'Hello, can you hear me?', or 'Is it working now?'. For Žižek to describe the use of community as a phatic statement would indicate not that the term is devoid of meaning. Instead community serves the social function of checking whether the channel of communication is open. Those in the community are consenting to being governed, just by being in the community whenever the term is applied. This might explain the attraction amongst policy-makers for using community. Community in any policy document being the equivalent of authorities saying 'can you hear me?', or 'is it 
p. 139. Polysemic, Polyvalent and Phatic: A Rough Evolution of Community With Reference to Low Carbon Transitions

working now?' to publics. Or, in the case of community funding schemes, vice versa: publics gesturing an acknowledgement of their presence to authorities.

Bringing phatic communion to bear on community in environmental governance is not just a linguistic exercise; it can also be political. If community low carbon projects and initiatives can be described as phatic, there is the possibility to use this critique to move beyond a solely semantic analysis of what community could possibly mean in the transition to low carbon futures. Polysemic approaches would likely produce a typology explicating the difference between 'communities of place' and 'communities of interest'. Conversely, linguistic approaches might take evidence that the term community is used in different ways, and indicate community as a (partially) floating signifier. Foucaldians might critique assumed values in community pointing to the coercion of publics engendered by the term's application. Communitarians might do something similar but for opposite ends: to return to community values in order to promote (partially lost) virtues. However the aim here is not to either defend the notion, content, feelings or values of community, but rather to seek a better theorisation of its actual use. Often the community of community transitions is phatic. With this in mind, what advantages might the recognition of community as phatic have?

1. Thinking more of the contact than content requires an assessment of why the word is used wherever it is found, rather than just identifying community's status as a 'god word' (Herbert, 2006), either for semantics or values. It is thus a thoroughgoing critical approach, asking of community cui bono: who does it serve?

2. When prompted to think deeper about why community is used, the next step might then be to think what synonyms might be used in its place. Can it be substituted by: communality, collectivity, fraternity, gang, locale, prison or inhabitants? Each of these takes us down a different road. The loss here is the absence of a 'warm fuzzy' application of the term; community's used and abused valences. But the gain is the word has greater purchase, it becomes far less nebulous.

3. The nebulous and phatic aspects to community can be seen as its advantage though, and help explain why community remains persistently attractive. Yet this is something to be taken to task. In environmental policy at times the clearer you are the greater the potential for disagreement. Showing more clearly the content, rather than contact, of the project that you want to get across can be a risk. Funders and policy makers regularly wish to present projects as successful, a clear definition can occlude this. Here, community as phatic appears as more post-political in analysis, smothering difference and contentious politics with the presentation of a community-based, pliant and positive population.

4. A phatic approach is not constrained by linguistic and semantic antics. Often the more productive question to be asked of community is not 'what does it mean?' but 'what does community do?'

5. Wootton (2016), following Agamben (1993), ties phatic communication to 'communication without communicability', which emphasises the 'trivial' over and against the 'involved'. This aids a critical adoption of phatic communion to help diagnose the community of low carbon transitions. For community transitions involvement is often a key aspect and reason for states enrolling subjects in low carbon tasks and activities. Phatic communication can shift this involvement towards the trivial. 
Identifying community as phatic can be a constructive alongside a critical addition. Phatic community does not need to only be negative. Just as the (supposed) moral valences of community have been adopted and utilised by different political persuasions: such as communitarians praising the inherent values of community and scholars of governmentality critiquing the very same aspects. Likewise, different groups can benefit from community's phatic function. Groups seeking funding can smuggle in progressive demands through a language of community. Yet critically, corporations and states can generate consent; using community as contact without content.

Community as phatic provides a language to be able to talk of disciplinary, or governmentalised community regimes of low carbon living without assuming community accompanies any specific morality or values. What matters is keeping the channel of communication open, states gaining consent by acknowledging a public's existence, but without equipping them with the genuinely political tools to change circumstances. Community can be deployed to control and consent in this analysis, not challenge and provoke. This matters in addition to theorising 'governing by community' as another angle to critique government misapplication of community. Identifying aspects of phatic communication in community responses to low carbon transitions also provides another important note to again be wary wherever community is found.

\section{Conclusion}

This paper attempts to make an informed and theoretical addition to notions of community. It is broad in scope, but tacks back to the use and abuse of community as it currently can be found within low carbon transitions, particularly in the UK. This potted rather than comprehensive history of community in the light of community policy, action and analysis allows gaps to be found. What are regularly seen as opposed viewpoints - deconstructive and essentialist readings of community - still have much in common: the semantic link. Communitarians and Foucaldians are also regularly set against each other, but both assume that community is value-laded. Fundamentally, this article argues for moving away from this, going beyond 'what does community mean?' Rather than seeing those challenging and progressive voices as directly opposed to a traditional, vanilla or beige community, this paper argues that anti-essentialist, deconstructive, or even Foucaldian readings of community haven't yet gone far enough. Critical research on community and scholars investigating the actual use and function of community need to be alive to community's phatic characteristics, as much as substituting one signifier or value for another.

\section{Acknowledgements}

Ray Aiken, Robin Jamieson and Amanda Taylor Aiken read over, provided lots of comments and helped provide advice in slimming down an unwieldy narrative in this paper. Liz Dinnie, Jan-Tobias Doerr, Rob Krueger, Bérénice Jung-Preller, Annabel Pinker and Christian Schulz all provided helpful comments after listening to the ideas discussed here. Harriet Bulkeley and Joe Painter both helped in narrowing and focusing the argument, and supervised the thesis out of which this paper emerges. Will Eadson provided encouragement to get this done and out, and the reviewers and Will as editor also helped sharpen and focus the text at key points. The usual disclaimers apply. 
p. 141. Polysemic, Polyvalent and Phatic: A Rough Evolution of Community With Reference to Low Carbon Transitions

\section{Notes}

1 Available from: http://www.transitionnetwork.org/support/what-transition-initiative [Accessed: 17 November 2015].

* Correspondence address: Gerald Taylor Aiken, Institute of Geography and Spatial Planning, Identités. Politiques, Sociétés, Espaces (IPSE), Faculté des Lettres, des Sciences Humaines, des Arts et des Sciences de I'Education. 2.135 Maison des Sciences Humaines. 11, Porte des Sciences L-4366 Esch-Belval. Email: gerald.aiken@uni.lu

\section{References}

Agamben, G. (1993) [2009] The Coming Community [Trans. Michael Hardt]. Minneapolis: MN: University of Minnesota Press.

Agyeman, J. (2005) Sustainable communities and the challenge of environmental justice. New York: New York University Press.

Aiken, G. (2012) Community transitions to low carbon futures in the transition towns network (TTN). Geography Compass, 6, 89-99.

Anderson, B. (1991) [1983] Imagined Communities: Reflections on the origin and spread of nationalism rev edn. London: Verso.

Bauman, Z. (2001) Community: Seeking Safety in an Insecure World. Cambridge: Polity.

Bell, C. and Newby, H. (1971) Community Studies. London: Unwin.

Bradbury, S. and Middlemiss, L. (2014) The role of learning in sustainable communities of practice. Local Environment. DOI:10.1080/13549839.2013.872091

Büchs, M. (2014) The role of environmental organisations in supporting carbon reduction: comparing direct and indirect involvement. Environmental Politics, 23 , 6, 1003-1022.

Bulkeley, H. (2005) Reconfiguring Environmental Governance: Towards a Politics of Scales and Networks. Political Geography, 24, 8, 875-902.

Bulkeley, H. and Fuller, S. (2012) Low carbon communities and social justice. JRF viewpoints Ref. 2741. York: Joseph Rowntree Foundation.

Bulkeley, H. and Newell, P. (2010) Governing Climate Change. London: Routledge.

Caputo, J. and Derrida, J. (1997) Deconstruction in a Nutshell: A Conversation with Jacques Derrida. New York, NY: Fordham University Press.

Cass, N. Walker, G. and Devine-Wright, P. (2010) Good Neighbours, Public Relations and Bribes: The Politics and Perceptions of Community Benefit Provision in Renewable Energy Development in the UK. Journal of Environmental Policy and Planning, 12, 3, 255-275.

Catney, P., MacGregor, S., Dobson, A., Hall, S.M., Royston, S., Robinson, Z., Mark Ormerod, M. and Ross, S. (2014) Big society, little justice? Community renewable energy and the politics of localism. Local Environment, 19, 7, 715-730.

Chatterton, P. (2014) Low Impact Living: A Field Guide to Ecological, Affordable Community Building. London: Routledge.

Chatterton, P. (2013) Towards an agenda for post-Carbon cities: Lessons from LILAC, the UK's first ecological, affordable, cohousing community. International Journal for Urban and Regional Research, 37, 1654-1674.

Claviez, T. and Nancy, J.-L. (foreword) (2016) The Common Growl: Towards a Poetics of Precarious Community. New York: Fordham University Press.

Cochrane, A. (2007) Understanding urban policy. London: Wiley Blackwell.

Cohen, A.P. (1985) The Symbolic Construction of Community. London: Tavistock. 
p. 142. Polysemic, Polyvalent and Phatic: A Rough Evolution of Community With Reference to Low Carbon Transitions

Creamer, E. (2015a) The double-edged sword of grant funding: a study of communityled climate change initiatives in remote rural Scotland. Local Environment, 20, 9, 981-99.

Creamer, E. (2015b) "Community": the means and ends of sustainability? Exploring the position and influence of community-led initiatives in encouraging more sustainable lifestyles in remote rural Scotland. Unpublished PhD Thesis, University of Edinburgh.

Crow, G. and Allen, G. (1994) Community life: an introduction to local social relations. London: Harvester Wheatsheaf.

Dark Mountain (2009) Uncivilisation: The Dark Mountain Manifesto. Available from: http://dark-mountain.net/about/manifesto/ [online] [Accessed: 1 November 2013].

DECC (2014) Community Energy Strategy. London: Department of Energy and Climate Change.

DECC (2012) Low carbon communities evaluation report. London: Department of Energy and Climate Change.

DeFilippis, J., Fisher, R. and Shragge, E. (2010) Contesting community the limits and potential of local organizing. Rutgers University Press.

DeFilippis, J., Fisher, R. and Shragge, E. (2006) Neither Romance Nor Regulation: Reevaluating Community. Int J Urban Reg Res, 30, 3, 673-89.

Delanty, G. (2010) Community. London: Routledge.

Derrida, J. (2000) Of Hospitality [Trans. R. Bowlby]. Stanford: Stanford University Press.

Douglas, M. (1966) Purity and Danger: An Analysis of Concepts of Pollution and Taboo. London: Routledge.

Eadson, W. (2016) State enrolment and energy-carbon transitions: Syndromic experimentation and atomisation in England. Environment and Planning: C Gov Policy. DOI: 10.1177/0263774X16629445

Eadson, W. and Foden, M. (2014) Critical perspectives on Community Energy. People, Place and Policy, 8, 3, 145-148.

Elliott, B. (2010) Constructing Community: Configurations of the Social in Contemporary Philosophy and Urbanism. Idaho Falls, ID: Lexington Books.

Elliott, B. (2009) Theories of Community in Habermas, Nancy and Agamben: A Critical Evaluation. Philosophy Compass, 4, 6, 893-903.

Esposito, R. (2010) Communitas: The origin and destiny of community. Stanford: CA: Stanford University Press.

Etzioni, A. (1997) The New Golden Rule: Community and Morality in a Democratic Society. London: Profile Books.

Etzioni, A. (1995) The Spirit of Community: Rights Responsibilities and the Communitarian Agenda. London: Fontana Press.

Featherstone, D. (2012) Solidarity: Hidden Histories and Geographies of Internationalism. London: Zed Books.

Foucault, M. (2009) Security, Territory, Population: Lectures at the Collège de France 1977-1978. Houndmills: Palgrave-Macmillan.

Franklin, A. and Marsden, T. (2015) (Dis)connected communities and sustainable place-making. Local Environment: The International Journal of Justice and Sustainability, 20, 8, 940-956.

Frazer, E. (1999) The Problem of Communitarian Politics: Unity and Conflict. Oxford: Oxford University Press.

Gibson-Graham, J.K. (2006) The End of Capitalism (As We Knew It): A Feminist Critique of Political Economy. Minneapolis, MN: University of Minnesota Press.

Gibson-Graham, J.K., Cameron, J. and Healy, S. (2013) Take Back the Economy: An ethical guide for transforming our communities. Minneapolis, MN: University of Minnesota Press. 
p. 143. Polysemic, Polyvalent and Phatic: A Rough Evolution of Community With Reference to Low Carbon Transitions

Habermas, J. (1998) The Inclusion of the Other: Studies in Political Theory [Trans. Ciaran Cronin]. Cambridge, MA: MIT Press.

Habermas, J. (1987) The Theory of Communicative Action, Vol. 2: Lifeworld and System: A Critique of Functionalist Reason [Trans. Thomas McCarthy]. London: Heinemann.

Habermas, J. (1984) The Theory of Communicative Action, Vol. 1: Reason and the Rationalization of Society [Trans. Thomas McCarthy]. London: Heinemann.

Hauxwell-Baldwin, R. (2013) Tackling Climate Change through Community: The Politics and Practice of the Low Carbon Communities Challenge. Unpublished PhD Thesis, University of East Anglia.

Heiskanen, E., Jalas, M., Rinkinen, J. and Tainio, P. (2015) The local community as a "low-carbon lab": promises and perils. Environmental Innovations and Societal Transitions, 14, 149-164.

Heiskanen, E., Johnson, M., Robinson, S., Vadovics, E. and Saaatamoinen, M. (2010) Low-carbon communities as a context for individual behavioural change. Energy Policy, 38, 7586-7595.

Herbert, S. (2006) Citizens, Cops and Power: Recognizing the Limits of Community. Chicago, IL: University of Chicago Press.

Howell, R. (2013) It's not (just) "the environment, stupid!" Values, motivations, and routes to engagement of people adopting lower-carbon lifestyles. Global Environmental Change, 23, 1, 281-290.

Jackson, T. (2009) Prosperity Without Growth: Economics for a Finite Planet. London: Earthscan.

Jackson, T. (2005) Motivating sustainable consumption: a review of evidence on consumer behaviour and behaviour change. A report to the Sustainable Development Research Network Centre for Environmental Strategy, University of Surrey.

Jakobson, R. (1960) Closing Statement: Linguistics and Poetics. In: T.A. Sebeok (ed.), Style in Language. New York, NY: Wiley: pp. 350-377.

Lee, D. and Newby H. (1983) The Problem of Sociology: an Introduction to the Discipline. London: Unwin Hyman.

Lovell, H. (2014) The multiple communities of low-carbon transition: an assessment of communities involved in forest carbon measurement. Local Environment. DOI:10.1080/13549839.2014.905515.

Maclntyre, A. (1981) After Virtue: A Study in Moral Theory. London: Duckworth.

Markantoni, M. and Woolvin, M. (2015) The role of rural communities in the transition to a low-carbon Scotland: a review. Local Environment, 20, 2, 202-19.

Mason, K. and Whitehead, M. (2012) Transition urbanism and the contested politics of ethical place making. Antipode, 44, 2, 493-516.

Middlemiss, L. (2014) Individualised or participatory? Exploring late-modern identity and sustainable development. Environmental Politics, 23, 6, 929-946.

Middlemiss, L. (2011a) The power of community: how community-based organizations stimulate sustainable lifestyles among participants. Society and Natural Resources, 24, 11, 1157-1173.

Middlemiss, L. (2011b) The effects of community-based action for sustainability on participants' lifestyles. Local Environment, 16, 3, 265-280.

Middlemiss, L. and Parrish, B. (2010) Building capacity for low-carbon communities: the role of grassroots initiatives. Energy Policy, 38, 12, 7559-66.

Moloney, S., Horne, R. and Fien, J. (2010) Transitioning to low carbon communitiesfrom behaviour change to systemic change: Lessons from Australia. Energy Policy, 38, 12, 7614-7623.

Moore, T. and McKee, K. (2012) Empowering local communities? An international review of community land trusts (policy review). Housing Studies, 27, 2, 280-90. 
p. 144. Polysemic, Polyvalent and Phatic: A Rough Evolution of Community With Reference to Low Carbon Transitions

Morton, T. (2010) The mesh, the strange stranger and the beautiful soul. In Mackay, R. (ed) Collapse Vl: geo/philosophy. Falmouth: Urbanonmic: pp. 265-293.

Morton, T. (2007) Ecology Without Nature: Rethinking Environmental Aesthetics. Cambridge, MA: Harvard University Press.

Mulugetta, Y., Jackson, T. and van der Horst, D. (2010) Carbon reduction at community scale (editorial). Energy Policy, 38, 7541-7545.

Nancy, J.-L. (2016) The Disavowed Community. New York: Fordham University Press.

Nancy, J.-L. (1991) The Inoperative Community. Minneapolis, MN: Minnesota University Press.

New Economics Foundation (2010) Good foundations: towards a low carbon, high wellbeing built environment. London: New Economics Foundation.

North, P. (2015) The business of the Anthropocene? Substantivist and diverse economies perspectives on SME engagement in local low carbon transitions. Progress in Human Geography. DOI: 10.1177/0309132515585049.

North, P. (2010) Eco-localisation as a progressive response to peak oil and climate change - A sympathetic critique. Geoforum, 41, 4, 585-594.

Pickerill, J. (2016) Eco-homes: people, place and politics. London: Zed books.

Pickerill, J. (2011) Building liveable cities: urban Low Impact Developments as low carbon solutions? In: Bulkeley, H., Castán Broto, V., Hodson, M. and Marvin, S. (eds) Cities and Low Carbon Transitions. London: Routledge: pp. 178-197.

Putnam, R. D. (2000) Bowling Alone: The Collapse and Revival of American community. New York, NY: Simon and Schuster.

Redfield, R. (1955) The Little Community. Chicago, IL: University of Chicago Press.

Rose, N. (1999) Powers of Freedom: Reframing Political Thought. Cambridge: Cambridge University Press.

Seyfang, G. (2009) Community action for sustainable housing: building a low carbon future. Energy Policy, 38, 12, 7624-33.

Seyfang, G. and Haxeltine, A. (2012) Growing grassroots innovations: exploring the role of community-based initiatives in governing sustainable energy transitions. Environment and Planning C: Government and Policy, 30, 381-400.

Seyfang, G. and Longhurst, N. (2013) Desperately seeking niches: grassroots innovations and niche development in the community currency field. Global Environmental Change, 23, 881-891.

Seyfang, G. and Smith, A. (2007) Grassroots innovations for sustainable development: towards a new research and policy agenda. Environmental Politics, 16, 4, 584603.

Shirani, F., Butler, C., Henwood, K., Parkhill, K. and Pidgeon, N. (2015) I'm not a tree hugger, I'm just like you': changing perceptions of sustainable lifestyles. Environmental Politics, 24, 1, 57-74.

Staeheli, L.A. (2008) Citizenship and the problem of community. Political Geography, 27, 1, 5-21.

Taylor Aiken, G. (2016) Prosaic state governance of community low carbon transitions. Political Geography, 55, 20-29.

Taylor Aiken, G. (2015) (Local-) Community for Global Challenges: carbon conversations, transition towns and governmental elisions. Local Environment, 20, 7, 764-781.

Taylor Aiken, G. (2014) Common Sense Community? The Climate Challenge Fund's Official and Tacit Community Construction. Scottish Geographical Journal, 3, 130, 3, 207-21.

Tönnies, F. (1955) [1887] Community and Association. London: Routledge.

Turner, V. (1969) The Ritual Process: Structure and Anti-Structure. Piscataway: Aldine Transaction. 
p. 145. Polysemic, Polyvalent and Phatic: A Rough Evolution of Community With Reference to Low Carbon Transitions

van Veelen, B. and Haggett, C. (2016) Uncommon ground: The role of different place attachments in explaining community renewable energy projects. Sociologia Ruralis. doi: 10.1111/soru.12128.

Walker, G. (2011) The role for 'Community' in carbon governance. Wiley Interdisciplinary Reviews: Climate Change, 2, 5, 777-782.

Walker, G. and Devine-Wright, P. (2008) Community renewable energy: what should it mean? Energy Policy, 36, 479-500.

Walker, G., Hunter, S., Devine-Wright, P., Evans, B. and Fay, H. (2007) Harnessing community energies: explaining and evaluating community-based localism in renewable energy policy in the UK. Global Environmental Politics, 7, 2, 64-82.

Warren, C.R. and McFadyen, M. (2010) Does community ownership affect public attitudes to wind energy? A case study from south-west Scotland. Land Use Policy, 27, 2, 204-213.

Wills, J. (2012) The geography of community and political organisation in London today. Political Geography, 31, 2, 114-126.

Wootton, M. (2016) 'Seeing each other for the first time': Politics and Social Media in Middle Class Cairo. Unpublished PhD Thesis, University of Durham.

Young, I.M. (1990) Justice and the Politics of Difference. Princeton, NJ: Princeton University Press.

Žižek, S. (2008) Violence. London: Profile. 